\title{
PELATIHAN WIRAUSAHA UNTUK MENINGKATKAN KUALITAS HIDUP ANAK JALANAN PADA KOMUNITAS ANAK JALANAN FLYOVER BALARAJA SERANG - BANTEN
}

Sudiarto*, Zackharia Rialmi, Sutiman

Dosen Fakultas Ekonomi. Universitas Pamulang

Emai1* : sudiarto132239@gmail.com

\begin{abstract}
ABSTRAK
Tulisan ini bertujuan untuk mengetahui sejauh mana sejauh mana keberhasilan mengembangkan semangat wirausaha untuk meningkatkan kualitas hidup anak jalanan pada Komunitas Anak Jalanan Flyover Balaraja Serang Banten

Teknik pendekatan dilakukan dengan metode seminar dan simulasi secara langsung

Hasil kegiatan dapat meningkatkan kualitas hidup, mengidentifikasi dan memanfaatkan potensi yang ada pada dirinya dengan baik.

\section{Kata Kunci : Sumber Daya Manusia, Potensi Diri, Wirausaha, Kualitas Hidup Anak Jalanan.}

\section{PENDAHULUAN}

Pengabdian kepada masyarakat merupakan pelaksanaan pengamalan ilmu pengetahuan, teknologi dan seni budaya langsung pada masyarakat secara kelembagaan melalui metodologi ilmiah sebagai penyebaran Tri Dharma Perguruan Tinggi serta tanggung jawab yang luhur dalam usaha mengembangkan kemampuan masyarakat, sehingga dapat mempercepat laju pertumbuhan tercapainya tujuan pembangunan nasional.

Kegiatan pengabdian masyarakat merupakan salah satu Tri Dharma Perguruan Tinggi Selain Pendidikan dan Penelitian, sesuai undang-Undang RI Nomor 20 Tahun 2003 tentang Sistem Pendidikan Nasional, pada Pasal 20 ayat 2 dinyatakan: "Perguruan Tinggi berkewajiban menyelenggarakan pendidikan, penelitian dan pengabdian masyarakat". Pada Pasal 24 ayat 2 disebutkan:"Perguruan tinggi memiliki otonomi untuk mengelola sendiri lembaganya sebagai pusat penyelenggaraan pendidikan tinggi, penelitian ilmiah, dan pengabdian masyarakat".

Program pengabdian kepada masyarakat merupakan salah satu program yang wajib dilaksanakan, baik oleh dosen maupun oleh mahasiswa, dengan berlandaskan pada prinsip-prinsip: motivasi pemenuhan kompetensi akademik, jiwa kewirausahaan (entrepreneurship), dan profesional, sehingga dapat menghasilkan program pengabdian kepada masyarakat yang bermutu, relevan, dan sinergis dalam meningkatkan pemberdayaan masyarakat.
\end{abstract}


Sasaran kegiatan Pengabdian kepada masyarakat (PKM) ini adalah dengan mengajak para anak-anak jalanan untuk mengikuti Penyuluhan dengan tema "Pelatihan Wirausaha Untuk Meningkatkan Kualitas Hidup Anak Jalanan Pada Komunitas Anak Jalanan Flyover Balaraja Serang - Banten "

\section{RUMUSAN MASALAH}

Berdasarkan latar belakang diatas dapat dirumuskan permasalahan sebagai berikut : Bagaimana mengembangkan semangat wirausaha untuk meningkatkan kualitas hidup anak jalanan pada Komunitas Anak Jalanan Flyover Balaraja Serang - Banten?

\section{TUJUAN}

Tujuan yang ingin dicapai dalam kegiatan ini adalah : Untuk mengetahui sejauh mana keberhasilan mengembangkan semangat wirausaha untuk meningkatkan kualitas hidup anak jalanan pada Komunitas Anak Jalanan Flyover Balaraja Serang - Banten

\section{KEGIATAN}

Sasaran dari program Pengabdian Masyarakat yang kami lakukan ini adalah anak jalanan yang tergabung dalam Komunitas flyover Balaraja dengan jumlah peserta pelatihan kurang lebih 50 orang

Adapun pelaksanan dari kegiatan adalah sebagai berikut:

$\begin{array}{ll}\text { Hari } & \text { : Rabu s/d Jumat } \\ \text { Tanggal/Bulan } & : 4 \text { s/d 6 Juli 2018 } \\ \text { Waktu } & : \text { Pukul 09.00 - 12.00 WIB } \\ \text { Tempat } & : \text { Komunitas Flyover Balaraja }\end{array}$

\section{APLIKASI}

Anak jalanan adalah sebuah istilah yang mengacu pada anak-anak tunawisma yang tinggal di wilayah jalanan. Lebih mendetail menurut UNICEF, anak jalanan yaitu berusia sekitar di bawah 18 tahun dan bertempat tinggal di wilayah kosong yang tidak memadai, serta biasanya tidak ada pengawasan.

Di tengah ketiadaan pengertian untuk anak jalanan, dapat ditemui adanya pengelompokan anak jalanan berdasar hubungan mereka dengan keluarga. Pada mulanya ada dua kategori anak jalanan, yaitu anak-anak yang turun ke jalanan dan anak-anak yang ada di jalanan. Namun pada perkembangannya ada penambahan kategori, yaitu anak-anak dari keluarga yang ada di jalanan.

Pengertian untuk kategori pertama adalah anak-anak yang mempunyai kegiatan ekonomi di jalanan yang masih memiliki hubungan dengan keluarga. Ada dua kelompok anak jalanan dalam kategori ini, yaitu anak-anak yang tinggal bersama orangtuanya dan senantiasa pulang ke rumah setiap hari, dan anak-anak yang melakukan kegiatan ekonomi dan tinggal di jalanan namun masih 
mempertahankan hubungan dengan keluarga dengan cara pulang baik berkala ataupun dengan jadwal yang tidak rutin.

Kategori kedua adalah anak-anak yang menghabiskan seluruh atau sebagian besar waktunya di jalanan dan tidak memiliki hubungan atau ia memutuskan hubungan dengan orangtua atau keluarganya.

Kategori ketiga adalah anak-anak yang menghabiskan seluruh waktunya di jalanan yang berasal dari keluarga yang hidup atau tinggalnya juga di jalanan.

Kategori keempat adalah anak berusia 5-17 tahun yang rentan bekerja di jalanan, anak yang bekerja dijalana, dan/atau yang bekerja dan hidup dijalanan yang menghabiskan sebagaian besar waktunya untuk melakukan kegiatan hidup seharihari.

Seorang anak yang mempunyai cita-cita yang tidak tercapai, karena ada sebuah faktor perekonomian keluarga, sehingga mereka mencarai uang tambahan jajan dengan cara mengamen di jalan dll.

Beberapa anak jalanan, khususnya di negara berkembang, merupakan anak yang ditelantarkan oleh orang tuanya. Selain itu, beberapa anak jalanan juga berasal dari keluarga dengan orang tua tunggal.

\section{Sumber Daya Manusia}

Sumber Daya Manusia (SDM) adalah individu produktif yang bekerja sebagai penggerak suatu organisasi, baik itu di dalam institusi maupun perusahaan yang memiliki fungsi sebagai aset sehingga harus dilatih dan dikembangkan kemampuannya. Pengertian sumber daya manusia makro secara umum terdiri dari dua yaitu SDM makro yaitu jumlah penduduk dalam usia produktif yang ada di sebuah wilayah, dan SDM mikro dalam arti sempit yaitu individu yang bekerja pada sebuah institusi atau perusahaan.

Sumber Daya Manusia (SDM) merupakan suatu hal yang sangat penting dan harus dimiliki dalam upaya mencapai tujuan organisasi atau perusahaan. Sumber daya manusia merupakan elemen utama organisasi dibandingkan dengan elemen sumber daya yang lain seperti modal, teknologi, karena manusia itu sendiri yang mengendalikan faktor yang lain.

Manajemen sumber daya manusia (MSDM) merupakan salah satu bidang dari manajemen umum yang meliputi segi-segi perencanaan, pengorganisasian, pelaksanaan dan pengendalian. Manajemen sumber daya manusia adalah suatu bidang manajemen yang khusus mempelajari hubungan dan peranan manusia dalam organisasi perusahaan. Menurut Hasibuan (2017:10), manajemen sumber daya manusia adalah: "Ilmu dan seni mengatur hubungan dan peranan tenaga kerja agar efektif dan efisien untuk membantu terwujudnya tujuan perusahaan, karyawan, dan masyarakat".

Sedangkan menurut Mangkunegara (2015: 2) Manajemen sumber Daya Manusia merupakan suatu perencanaan, pengorganisasian, pengoordinasian, pelaksanaan dan pengawasan terhadap pengadaan, pengembangan, pemberian balas jasa, pengintegrasian, pemeliharaan dan pemisahan tenaga kerja dalam rangka mencapai tujuan organisasi. 


\section{Potensi Diri}

Potensi diri merupakan kemampuan, kekuatan, baik yang belum terwujud maupun yang telah terwujud, yang dimiliki seseorang, tetapi belum sepenuhnya terlihat atau dipergunakan secara maksimal oleh seseorang.

Secara umum, potensi dapat diklasifikasikan sebagai berikut :

1. Kemampuan dasar, seperti tingkat intelegensi, kemampuan abstraksi, logika dan daya tangkap.

2. Etos kerja, seperti ketekunan, ketelitian, efisiensi kerja dan daya tahan terhadap tekanan.

3. Kepribadian, yaitu pola menyeluruh semua kemampuan, perbuatan, serta kebiasaan seseorang, baik jasmaniah, rohaniah, emosional maupun sosial yang ditata dalam cara khas di bawah aneka pengaruh luar.

Menurut "Howard Gardner", potensi yang terpenting adalah intelegensi, yaitu sebagai berikut:

1. Intelegensi linguistik, intelegensi yang menggunakan dan mengolah katakata, baik lisan maupun tulisan, secara efektif. Intelegensi ini antara lain dimiliki oleh para sastrawan, editor, dan jurnalis.

2. Intelegensi matematis-logis, kemampuan yang lebih berkaitan dengan penggunaan bilangan pada kepekaan pola logika dan perhitungan.

3. Intelegensi ruang, kemampuan yang berkenaan dengan kepekaan mengenal bentuk dan benda secara tepat serta kemampuan menangkap dunia visual secara cepat. Kemampuan ini biasanya dimiliki oleh para arsitek, dekorator dan pemburu.

4. Intelegensi kinestetik-badani, kemampuan menggunakan gerak tubuh untuk mengekspresikan gagasan dan perasaan. Kemampuan ini dimiliki oleh aktor, penari, pemahat, atlet dan ahli bedah.

5. Intelegensi musikal, kemampuan untuk mengembangkan, mengekspresikan dan menikmati bentuk-bentuk musik dan suara. Kemampuan ini terdapat pada pencipta lagu dan penyanyi.

6. Intelegensi interpersonal, kemampuan seseorang untuk mengerti dan menjadi peka terhadap perasaan, motivasi, dan watak temperamen orang lain seperti yang dimiliki oleh seseorang motivator dan fasilitator.

7. Intelegensi intrapersonal, kemampuan seseorang dalam mengenali dirinya sendiri. Kemampuan ini berkaitan dengan kemampuan berefleksi (merenung) dan keseimbangan diri.

8. Intelegensi naturalis, kemampuan beradaptasi dengan lingkungan alam

Sementara sebagaimana dijelaskan dalam Kurikulum 2004, kecakapan hidup adalah "Kecakapan yang dimiliki seseorang untuk mampu memecahkan permasalahan hidup secara wajar dan menjalani kehidupan secara bermartabat tanpa merasa tertekan, kemudian secara proaktif mencari serta menemukan solusi, sehingga akhirnya mampu mengatasinya".

Berdasarkan pengertian di atas, kecakapan hidup (life skills) merupakan kecakapan untuk memecahkan masalah secara inovatif dengan menggunakan fakta, 
konsep, prinsip atau prosedur yang telah dipelajari. Pemecahan masalah tersebut dapat berupa proses maupun produk yang bermanfaat untuk mempertahankan, meningkatkan, atau memperbaharui hidup dan kehidupan siswa.

Kecakapan hidup tersebut diharapkan dapat dicapai melalui berbagai pengalaman belajar siswa.Dari berbagai pengalaman mempelajari berbagai mata pelajaran, diharapkan siswa memperoleh hasil sampingan yang positif berupa upaya memanfaatkan pengetahuan, konsep, prinsip dan prosedur untuk memecahkan masalah baru dalam bentuk kecakapan hidup.Di samping itu, kecakapan hidup tersebut hendaknya diupayakan pencapaiannya dengan mengintegrasikannya pada topik dan pengalaman belajar yang relevan (Depdiknas, 2003).

Dengan demikian, life skills memiliki makna yang lebih luas dari kecakapan kerja tertentu (vocational skills).Life skills lebih tepat diartikan sebagai kecakapan hidup. Pengertian kecakapan hidup di sini, tidak semata-mata berarti memiliki kemampuan tertentu saja, namun ia harus memiliki kompetensi dasar pendukungnya, seperti membaca, menulis, menghitung, merumuskan dan memecahkan masalah, mengelola sumber daya, bekerja dalam tim atau kelompok, terus belajar di tempat bekerja, mempergunakan teknologi, dan lain sebagainya.

Life skills (kecakapan hidup) menunjuk pada berbagai ragam kemampuan seseorang untuk menempuh kehidupan dengan sukses, bahagia dan secara bermartabat di dalam masyarakat. Life skills merupakan kemampuan sepanjang hayat, kepemilikan kemampuan berpikir yang kompleks, kemampuan komunikasi secara efektif, kemampuan membangun kerjasama, melaksanakan peranan sebagai warga negara yang bertanggungjawab, memiliki kesiapan serta kecakapan untuk bekerja, memiliki karakter dan etika untuk terjun ke dunia kerja (Depdiknas, 2003).

Berdasarkan pengertian life skills sebagaimana diuraikan di atas, pendidikan kecakapan hidup dapat difahami sebagai usaha untuk membantu dan membimbing aktualisasi potensi peserta didik untuk mencapai sejumlah kompetensi, baik berupa pengetahuan, keterampilan, sikap dan nilai yang mengarah pada permasalahan hidup, menjalani kehidupan secara mandiri dan bermartabat, serta proaktif dalam mengatasi masalah.

Pendidikan kecakapan hidup menurut Tim BBE Depdiknas (2002) pendidikan kecakapan hidup (Life Skills Education) merupakan proses pendidikan yang mengarah pada pembekalan kecakapan seseorang, untuk mampu dan berani menghadapi problema hidup dan kehidupan secara wajar, tanpa merasa tertekan, kemudian secara proaktif dan kreatif mencari solusinya, sehingga akhirnya mampu mengatasi problema tersebut.

Penjelasan pasal 26 ayat 3 UU No. 20 Tahun 2003 tentang Sistem Pendidikan Nasional menyebutkan bahwa pendidikan kecakapan hidup (life skills education) adalah "Pendidikan yang memberikan kecakapan personal, sosial, intelektual dan kecakapan vokasional untuk bekerja atau usaha mandiri". 


\section{Wirausaha}

Kewirausahaan (Entrepreneurship) atau Wirausaha adalah proses mengidentifikasi, mengembangkan, dan membawa visi ke dalam kehidupan Visi tersebut bisa berupa ide inovatif, peluang, cara yang lebih baik dalam menjalankan sesuatu. Hasil akhir dari proses tersebut adalah penciptaan usaha baru yang dibentuk pada kondisi risiko atau ketidakpastian.

Kewirausahaan memiliki arti yang berbeda-beda antar para ahli atau sumber acuan karena berbeda-beda titik berat dan penekanannya. Richard Cantillon (1775), misalnya, mendefinisikan kewirausahaan sebagai bekerja sendiri (selfemployment). Seorang wirausahawan membeli barang saat ini pada harga tertentu dan menjualnya pada masa yang akan datang dengan harga tidak menentu. Jadi definisi ini lebih menekankan pada bagaimana seseorang menghadapi risiko atau ketidakpastian.

Berbeda dengan para ahli lainnya, menurut Penrose (1963) kegiatan kewirausahaan mencakup indentfikasi peluang-peluang di dalam sistem ekonomi sedangkan menurut Harvey Leibenstein $(1968,1979)$ kewirausahaan mencakup kegiatan yang dibutuhkan untuk menciptakan atau melaksanakan perusahaan pada saat semua pasar belum terbentuk atau belum teridentifikasi dengan jelas, atau komponen fungsi produksinya belum diketahui sepenuhnya dan menurut Peter Drucker, kewirausahaan adalah kemampuan untuk menciptakan sesuatu yang baru dan berbeda. Orang yang melakukan kegiatan kewirausahaan disebut wirausahawan. Muncul pertanyaan mengapa seorang wirausahawan (entrepreneur) mempunyai cara berpikir yang berbeda dari manusia pada umumnya. Mereka mempunyai motivasi, panggilan jiwa, persepsi dan emosi yang sangat terkait dengan nilai nilai, sikap dan perilaku sebagai manusia unggul (wikipedia)

Wirausaha secara historis sudah dikenal sejak diperkenalkan oleh Richard Castillon pada tahun 1755. Di luar negeri, istilah kewirausahaan telah dikenal sejak abad 16, sedangkan di Indonesia baru dikenal pada akhir abad 20. Beberapa istilah wirausaha seperti di Belanda dikenal dengan ondernemer, di Jerman dikenal dengan unternehmer. Pendidikan kewirausahaan mulai dirintis sejak 1950-an di beberapa negara seperti Eropa, Amerika, dan Kanada. Bahkan sejak 1970-an banyak universitas yang mengajarkan kewirausahaan atau manajemen usaha kecil.

Pada tahun 1980-an, hampir 500 sekolah di Amerika Serikat memberikan pendidikan kewirausahaan. DI Indonesia, kewirausahaan dipelajari baru terbatas pada beberapa sekolah atau perguruan tinggi tertentu saja. Sejalan dengan perkembangan dan tantangan seperti adanya krisis ekonomi, pemahaman kewirausahaan baik melalui pendidikan formal maupun pelatihan-pelatihan di segala lapisan masyarakat kewirausahaan menjadi berkembang. Proses kewirausahaan

Menurut Carol Noore yang dikutip oleh Bygrave, proses kewirausahaan diawali dengan adanya inovasi. Inovasi tersebut dipengeruhi oleh berbagai faktor baik yang berasal dari pribadi maupun di luar pribadi, seperti pendidikan, sosiologi, organisasi, kebudayaan dan lingkungan. Faktor-faktor tersebut membentuk 'locus 
of control', kreativitas, keinovasian, implementasi, dan pertumbuhan yang kemudian berkembangan menjadi wirausahawan yang besar.

Secara internal, keinovasian dipengaruhi oleh faktor yang bersal dari individu, seperti locus of control, toleransi, nilai-nilai, pendidikan, pengalaman. Sedangkan faktor yang berasal dari lingkungan yang memengaruhi diantaranya model peran, aktivitas, dan peluang. Oleh karena itu, inovasi berkembang menjadi kewirausahaan melalui proses yang dipengaruhi lingkungan, organisasi, dan keluarga.

Seorang wirausaha berperan baik secara internal maupun eksternal. Secara internal seorang wirausaha berperan dalam mengurangi tingkat kebergantungan terhadap orang lain, meningkatkan kepercayaan diri, serta meningkatkan daya beli pelakunya. Secara eksternal, seorang wirausaha berperan dalam menyediakan lapangan kerja bagi para pencari kerja. Dengan terserapnya tenaga kerja oleh kesempatan kerja yang disediakan oleh seorang wirausaha, tingkat pengangguran secara nasional menjadi berkurang.

Menurunnya tingkat pengangguran berdampak terhadap naiknya pendapatan perkapita dan daya beli masyarakat, serta tumbuhnya perekonomian secara nasional. Selain itu, berdampak pula terhadap menurunnya tingkat kriminalitas yang biasanya ditimbulkan oleh karena tingginya pengangguran.

\section{Kualitas Hidup Anak Jalanan}

Meningkatkan kualitas hidup anak jalanan adalah tanggung jawab kita bersama khususnya kita sebagai akademisi, meningkatkan kualitas hidup mereka bukan hanya saja memberi kereka sumbangan berupa santunan uang, makanan dan pakaian, tetapi lebih kepada memberikan mereka bekal untuk melanjutkan hidupnya dimasa yang akan datang.

Memutuskan rantai kehidupan anak jalananbisa dimulai melalui sumbernya. Jika orang-orang tak lagi memberi uang ke anak jalanan, mereka akan berpikir bahwa hidup meminta-minta di jalan bukan lagi hal yang menguntungkan untuk dilakukan.

Kendati demikian, ada cara lain yang dapat dilakukan untuk membantu anak jalanan selain memberi uang, yaitu dengan menjadi relawan. Menjadi relawan tidak memerlukan modal yang besar, cukup dengan menjadi sahabat mereka untuk bermain dan berbincang bersama.

Berbaur menjadi mata pelajaran yang perlu dikuasai relawan. Dengan menjadi bagian yang sama, anak-anak jalanan tak akan sungkan dan menutup diri untuk bercerita dan menghapus kesenjangan. Dengan menyertakan diri ke kaum marginal dapat membuka kepekaan terhadap apa yang mereka butuhkan dan apa yang bisa kita berikan.

Membentuk sanggar-sanggar, rumah singgah dan komunitas adalah hal yang sangat dibutuhkan bagi mereka para anak jalanan. Sehingga mereka akan lebih terarah dalam menghadapi masa depan dengan tantangan-tantangan globalisasi didalamnya. 


\section{STRATEGI}

Dalam pelatihan ini menggunakan teknik seminar, simulasi, pendekatan persuasif kepada peserta dan diberikan motivasi untuk meningkatkan pengetahuan wirausaha untuk meningkatkan kualitas hidup anak jalanan di masa yang akan datang

\section{PENUTUP}

Pelaksanaan kegiatan pengabdian masyarakat oleh lembaga penelitian dan pengembangan masyarakat (LPPM) Universitas Pamulang yang dilakukan oleh dosen-dosen program studi manajemen telah berjalan dengan lancar dan mendapat sambutan hangat dari tempat pelaksanaan kegiatan ini yaitu para para anak jalanan, diharapkan dengan kegiatan ini anak jalanan mampu meningkatkan kualitas hidupnya dan mampu mengembangkan potensi diri untuk berwirausaha agar kehidupannya bisa lebih sejahtera di masa yang akan datang.

\section{DAFTAR REFERENSI}

Hasibuan, Malayu S.P. 2017. Manajemen Sumber Daya Manusia Edisi Revisi. Jakarta: PT. Bumi Aksara

Mangkunegara, Anwar Prabu. 2015. Manajemen Sumber Daya Manusia Perusahaan. Bandung: PT Remaja Rosdakarya

https://id.wikipedia.org/wiki/Kewirausahaan

\section{DOKUMENTASI FOTO KEGIATAN}

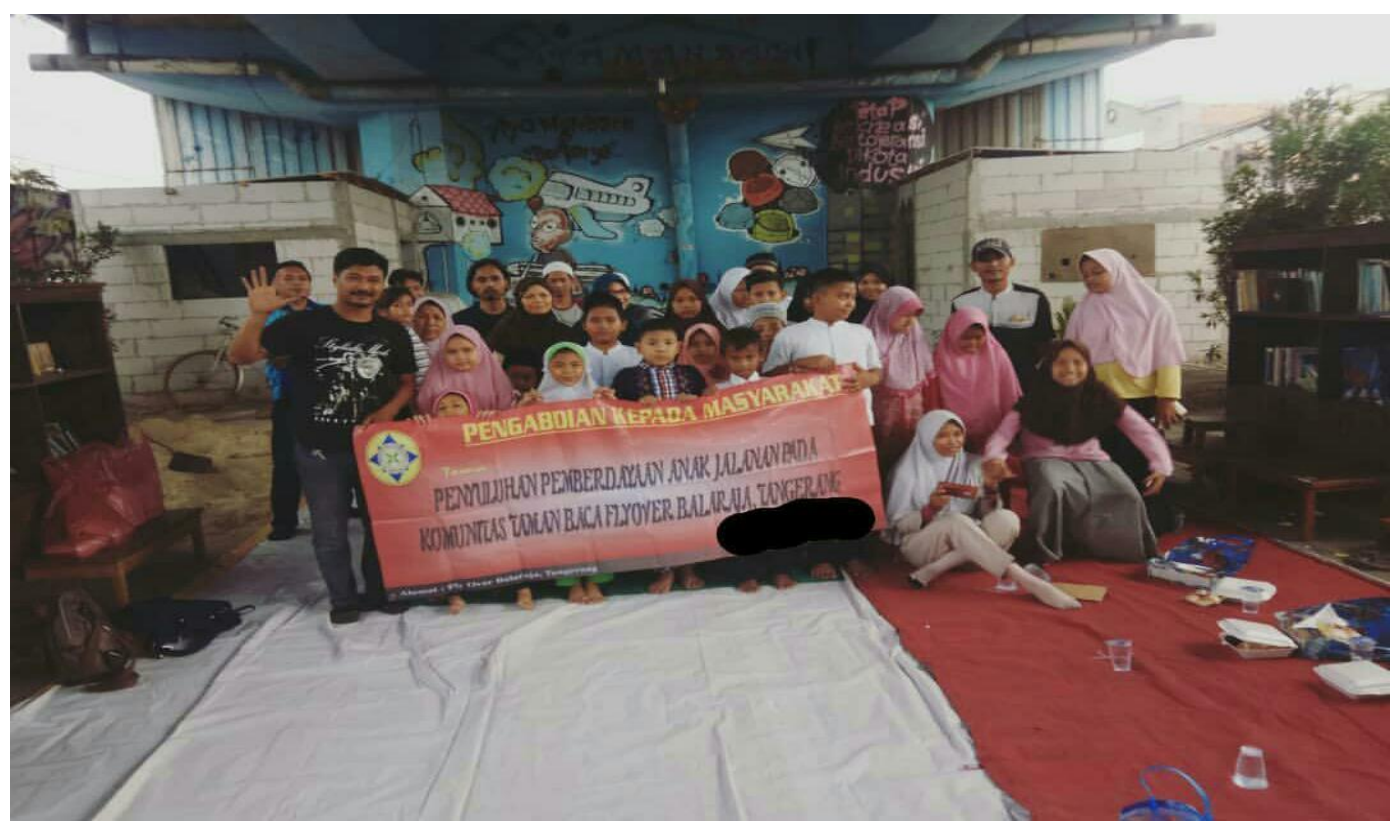



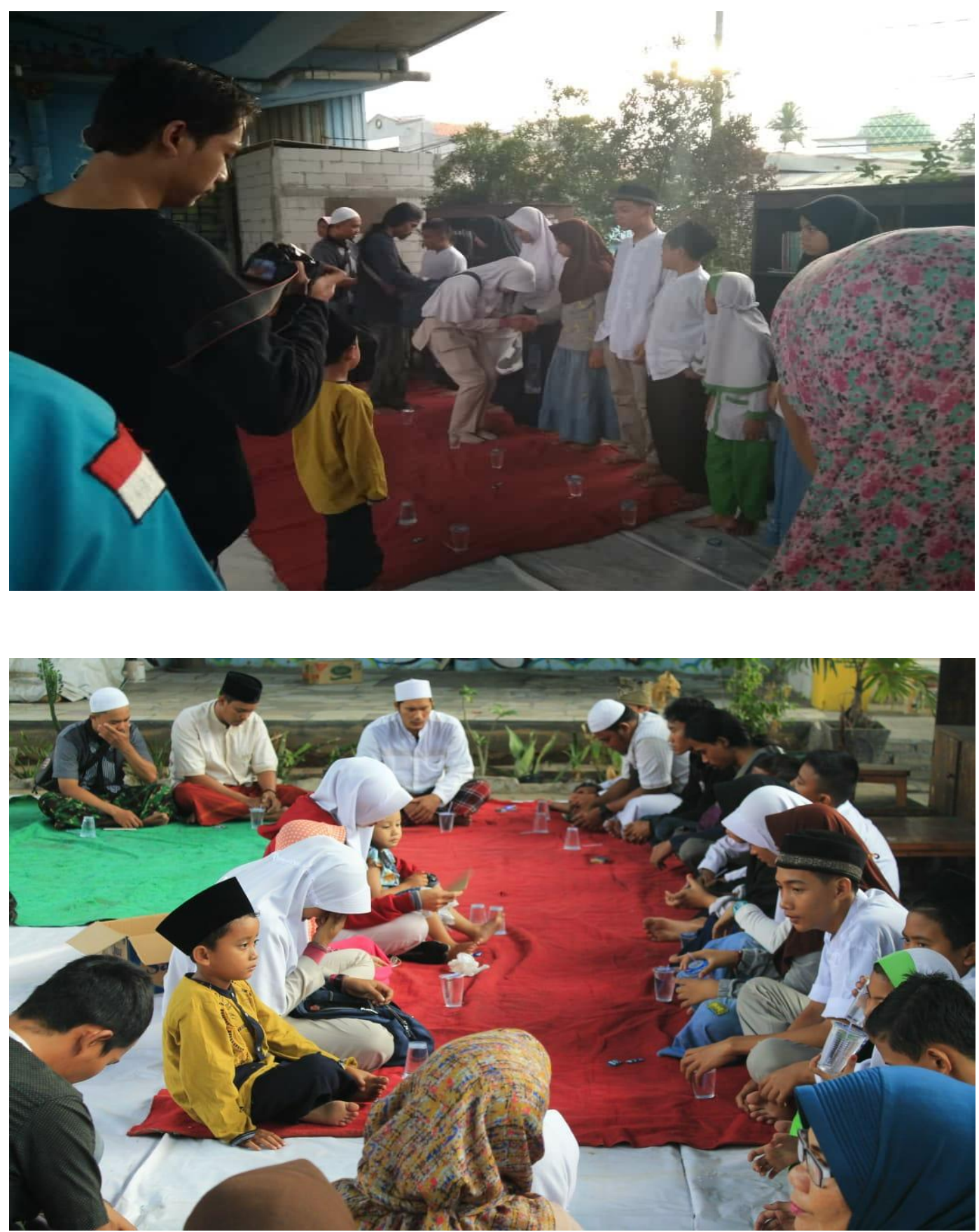